\title{
The Social Accountability Report within the Chambers of Commerce: Theory, Procedure and Empirical Evidence
}

\author{
Ubaldo Comite $^{1} \&$ Nadia Oliva ${ }^{1}$ \\ ${ }^{1}$ Telematic University "Giustino Fortunato", Benevento, Italy \\ Correspondance: Nadia Oliva, Telematic University Giustino Fortunato, Viale Delcogliano, 12 Benevento, Italy. Tel: \\ 39-328-465-0868.
}

Received: October 24, 2017

Accepted: November 13, 2017

Online Published: November 21, 2017

doi:10.5430/jms.v8n5p55

URL: https://doi.org/10.5430/jms.v8n5p55

\begin{abstract}
In Italy, many companies and central and local public administration offices, including the Chambers of Commerce, are turning to new forms of accounting of their results. Amongst these, the social accountability report definitely represents an innovative tool; an innovation intended to guarantee compliance with the principles of accountability and social control, that are growing strong within the wider process of transparency and accessibility of management data, as well as the use of the resources, which involves the whole Public Administration. The social accountability report is presented as a non-accounting tool meant to spread a systemic and structured vision of the activities carried out and of the results obtained by the administration in reference to the period of the ending mandate.

The aim of the work is to examine in depth the issue of social reporting in the Chambers of Commerce, referring in particular to the social accountability report, highlighting its potential and its criticalities through a theoretical, empirical and methodological analysis. By using the empirical analysis, we are going to show, first of all, the composition and the territorial distribution of social reporting in the Chambers of Commerce between 1999 and 2016. By offering, later on, a case study, such as the social accountability report of the Chamber of Commerce of Treviso, we will show how the experiences of the Chambers of commerce relating to social reporting are so heterogeneous that the several reports produced often show some significant peculiarities on a structural level. In the knowledge that such heterogeneity represents, however, a methodological enhancement, the work will later show a standard social accountability report for the Chambers of Commerce that is a result of the adaptation and reasoned integration of the contents of the social accountability reports produced by the Chambers of Commerce so far.
\end{abstract}

Keywords: social accountability report, public administration, chamber of commerce

\section{Introduction}

In the first half of the 1990s, the system of the Chambers of Commerce underwent a deep functional reorganization. The Regulation n ${ }^{\circ} 580$ (Note 1), dated 29 December 1993 as modified by Lgs. D. n`23 (Note 2) dated 15 February 2010 conferred them ... within the pertaining area, functions of general interest for the system of enterprises, seeing to their development within local economies

(Figure 1). 


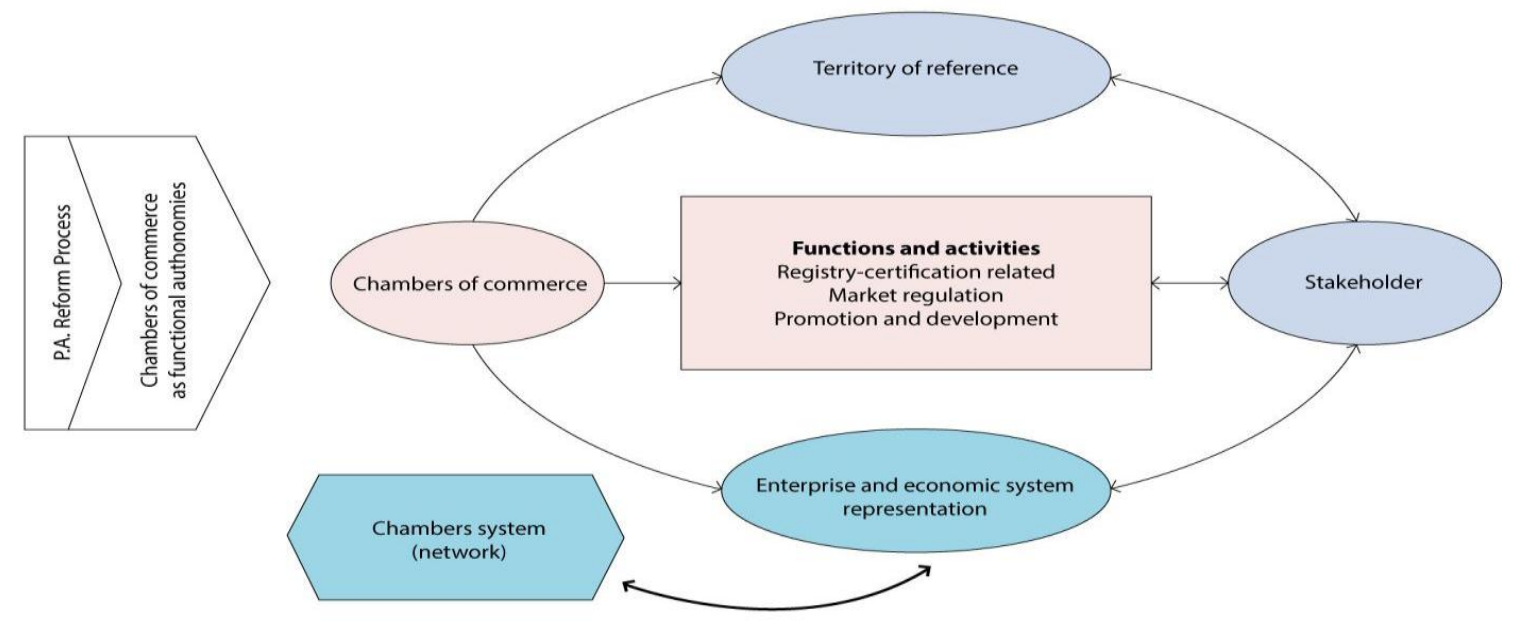

Figure 1. The mission of the Chamber of Commerce

Source: Unioncamere (2005), The Chambers of Commerce Network. Social Report of the Chambers of Commerce, I Focus of Unioncamere 2005 on social reporting. (www.bilanciosociale.cameradicommercio.it).

The Chambers of Commerce evolve from being bodies in charge of carrying out public function solely upon State mandate, to recipient of public assignments that, despite being fixed by law, have their own organization that can decline its duties in order to respond to the needs of the socio-economic body from which it emanates.

This regulation has been later overtaken by the Lgs. Decree of the Madia reform (Note 3).

In this context, the Chambers of Commerce have felt the need to experiment new forms of accounting, such as the social accountability report, that goes beyond the mere report required by Law. The social accountability report is presented as a non-accounting tool aimed at spreading a systemic and structured vision of the activities carried out and of the results obtained by the administration in referral to the time span of the ending mandate. The "accounting" of the results obtained entails a close examination of the economic, human and operating resources put in place to support the planning and administrative operation of the Entity, meant to focus the attention on the repercussions and the benefits produced to the advantage of its main stakeholders. By giving value to the relationship of mutual trust with its stakeholders, the Entity responds to their needs and expectations of information with yet another explanatory tool able to make accessible and perceptible the level of responsibility and efficacy of its conduct in the achievement of the institutional mission, during the whole timeframe of the mandate. The document develops through a description of the quantity and quality of the work carried out and considers the results of the programs carried out both in terms of results (output) significant from the point of view of efficiency and efficacy of the action, and in terms of economic impact produced (outcome on the local economic and territorial system). The analysis of the actions carried out and the objectives achieved is developed on the basis of the editing of the strategic priorities delineated with the multiannual programming along a given time span which encompasses the entire period of full activity of the Board, that goes from the date of the assignment to the end of the mandate.

\section{The Concept of Social Reporting}

The problem of reporting, intended as a structured form of communication, is mostly a demonstration of coherence between the institutional goal, the declared mission, the management and decisional ways, the results produced and the measurements that express the goals achieved - to be interpreted by taking into account the environmental, territorial and cultural scenario of improvement of the quality of life, of economic progress, etc. - according to the logic of triple bottom line (Note 4).

To the reporting intended this way, we assign the qualification of "social".

The diffusion of tools that are suitable to carry out this type of work has first taken place in the profit sector companies, then in the non-profit organizations and only very recently in the public sector and, within it, in local areas, in the chambers of commerce (Note 5). 
Social reporting consists, then, of a structured way to communicate the government action - stimulating the participation - seized in the "social" aspect broadly intended, meaning that it includes the several environmental and human profiles, including those of "economic - financial" nature (Table 1).

Table 1. Difference between accounting reporting and social reporting

\begin{tabular}{|c|c|c|}
\hline & Accounting Reporting & Social Reporting \\
\hline \multirow[t]{2}{*}{ Value } & It's mandatory by Law & It's an ethical option \\
\hline & $\begin{array}{l}\text { The control bodies of } \\
\text { monitoring entities }\end{array}$ & $\begin{array}{l}\text { stakeholders: subjects affected by the } \\
\text { activities of the Body }\end{array}$ \\
\hline $\begin{array}{r}\text { What information does } \\
\text { it provide }\end{array}$ & $\begin{array}{l}\text { The destination of the financial } \\
\text { resources, assignment to the } \\
\text { various balance sheet items, } \\
\text { use. }\end{array}$ & $\begin{array}{l}\text { The results achieved by employing the } \\
\text { available economic resources, that is } \\
\text { the social consequence determined by } \\
\text { the actions undertaken }\end{array}$ \\
\hline
\end{tabular}

Fonte: Unioncamere (2005), The Chambers of Commerce Network. Social Report of the Chambers of Commerce, I Focus of Unioncamere 2005 on social reporting (www.bilanciosociale.cameradicommercio.it).

In this regard it is to be pointed out that, in public institutes that express levels of government, the financial prospect assumes a prominent importance compared to a simple obligation applied to the realization of humanistic-environmental objectives (Note 6).

The decisions of a financial nature, in such context, have an importance that is strictly linked to the general objectives of the organization, since the choices involving the finding and assignment of the financial resources outline a government will that deeply impacts the social aspects, since - as the case might be - they promote, in a way that can be more or less intense, the process of redistribution of wealth and, more widely, produce different visions of development of the Society (Note 7).

In public institutions, social reporting constitutes an incentive to promote cost effectiveness (Note 8). As a matter of fact, for public administrations in general and for the Chambers of Commerce in particular, social reporting is a favorable occasion to define their identity, and, in strict coherence, to carry out a strategic programming, in line with the political planning, to be desirably followed by coherent behavior and coherent results.

Essentially, the underlying logic of social reporting is endowed with a high potentiality to promote participation, and therefore to obtain sharing and information that are of great help to the rationalization of the government action. Clearly, the possible results of social reporting are not to be thought of as mere educational tools, but rather as means to improve the actions of government, also via the impulse that external information based on sociability can give to the development of the public control on the operations of public administration (Note 9).

The document that is mostly used to realize social reporting has been deemed to be, by many, the social report and, within this macro-area, the social accountability report.

In public administrations, amongst which are the Chambers of Commerce, accountability has mostly taken up the role of social responsibility and, therefore, of need for transparency and accounting of the effects of the management policies on the community managed and on the economic systems within the time span of the so called "political mandate".

\section{Social Accountability Report of the Chambers of Commerce: Definition and Criticalities}

The political component characterizing public administration is an element that as an effect, under an accounting point of view, on the editing of the social accountability report.

The social accountability report is a document that, at the end of the political mandate, highlights the level of achievement of the objectives promised upon assignment of the political entities on the basis of the specified program. One attempt to define its outline can be to identify the social accountability report in the tool through which the administration communicates the results achieved, at the end of the three-year term mandate, to the stakeholders, in terms of modality, priority and level of achievement of objectives declared in the administrative program. The goal of such document is therefore represented by the establishment of a comparison with the administrative community regarding the political ability to achieve the objectives declared at the beginning of the mandate and thanks to which it 
has obtained trust.

In light of the above, the need for comparison, within the social accountability report, between the results obtained and the programs presented at the beginning of the mandate becomes evident. They reflect in the guidelines of the entity and in the general development plan. At the end of the government period, the cycle ends through the end-of-mandate report. In the integrated course of programming and control in which is inserted the editing of a social accountability report, it is necessary to introduce the editing of an initial state and an end-of- mandate state, to calculate indicators that are useful to the community in terms of evaluating the administrative action, etc.

This synthetic presentation of the essential guidelines that characterize the social accountability report, allow a few considerations regarding the possible criticalities of this tool within the context of the Chambers of Commerce.

First of all, the political style of the end-of-mandate report appears evident. As a matter of fact, initially the end-of-term report originates from the political program edited by the Board of the Chamber of Commerce. Despite such program shows in other documents within the Entity, it is to be noted that the reporting is produced at the end of the administrative mandate, underlying, therefore, the direct responsibility of the outgoing political class in the administrative activity that is the object of the social accountability report. It is also true that other reporting tools, such as the social report and the environmental report, may underline the ability of the political class to pursue certain objectives, but it is an indirect consequence of the reporting activity: such presumed ability is not specifically connected to the political entities, but at the body in its entirety. Furthermore; it is an evaluation to be left to the reader and, in any case, a direct consequence of the administrative activity carried out and communicated through the social report or the environmental report. On the contrary, the main objective of end-of-term reporting is to assess the political ability to keep the promises made at the beginning of the mandate. Therefore, it appears evident that there is a risk of bias in the information contained in the document: the end-of-term reporting, as a matter of fact, is exposed to the possibility of an omission of information that can result to be unfavorable to the outgoing government class.

Furthermore, such risk is reinforced by the intentional nature of the document, that could lead to the editing of it only if the results obtained by the administration are in line with what was promised at the beginning of the mandate.

So, the social accountability report originates in the public sector, it is of political nature and carries out an informative function toward the public regarding keeping the promises made by the government entity at the beginning of the mandate. The document includes the trend of the entire administrative setting of the Entity, of which not only the effects are evaluated, but the actions carried out, too.

In summary, the social accountability report is different from the more general social report since it is edited in a completely different context: the context of the agent that, having undertaken specific duties for carrying out a certain task, sees to report his own actions at the end of the mandate. The content of the social accountability report is totally different from the social report. It will follow a course that is articulated according to specific topics and will see the variation of bot the subjective and objective reference points (Note 10).

\section{Social Reporting in the Chambers of Commerce: Methodological and Standard In-depth Analysis of Content}

In the last few years, the issues regarding social reporting have been involving the public sector, and therefore the Chambers of Commerce, as well as the private sector. This is due to the need of the Chamber's Entity to create, being it a public body, shared social value as well as the resulting need to acquire credibility and reputation (Note 11).

In general terms, as very well outlined by Romolini: “[...] public administration is, by definition, responsible toward the community. The need to account for the results obtained and their social consequences is placed, therefore, within the scope of its duties, and not in the range of options to choose" (Note 12). The public entity nature constitutes, at least on a theoretical plane, the prerequisite for a strict interdependence between administrative management and community goal. If this is true, then the twisting effects that are typical in the mandate processes would result to be null and the Entity would carry out its function at the fullest, acquiring, as underlined above, full credibility and reputation. However, if this prerequisite fails to be- that is, as conveniently underlined by Pavan "if the interests of the public administrations do not naturally coincide with [...] a common interest and if such subject are the first carriers of the power to make decisions, then, it can be very easily verified that the public organizations are in fact directed [...] toward objectives that have nothing to do [...] with the public interest". From this point stems the need to "emphasize the definition of objectives to put into concrete action: quantified, timed, sensitive to the qualitative dimension, measurable in the final balance" (Note 13). 
In hindsight, however, such duty should be of a more than regulatory nature, since social reporting in public administration, and therefore in Chambers of Commerce also, is voluntary. The entity, therefore, is free to choose whether or not to account for the social effect of its actions, and it is also free to choose both the accounting form and method.

One important feature of social reporting in Chambers of Commerce bodies is the heterogeneity of the usable reports. There are, in fact, short term reports (such as the classic social report) or medium term reports (such as the social accountability report). While the properly called social report has as its main objective to periodically report the social effects of the activity of the Chamber, regardless of whoever was in charge of it, the social accountability report provides an account of the social effects of the actions of the Chamber as the expression of that particular management by the President of the Chamber or its highest representative in charge (Note 14).

Moreover, social reporting can show all the effects of the management (like in the case of the social report or the end-of-mandate report) or some effects in particular, like in the case of the environmental report, that has as an objective to show the environmental effects of the action of the interested Body, or like the case of the Gender Report, that has as an objective to show the effects of the actions of the Entity on certain categories of individuals such as women, youngsters, etc.... or, eventually, the sector report, whose objective is to provide information on the social effects concerning special action areas of the Entity (Note 15).

Lastly, the social reports may look at the direct relationship between the Entity and the stakeholders (as in the case of the social report) or at the indirect relationship between the Entity and the stakeholders in an ample territorial context (as in the case of the consolidated statement or the territorial statement) (Note 16).

Social reporting in the Chambers of commerce must be carried out respecting a series of consolidated principles such as periodicity, completeness, intelligibility, clarity of information provided, truthfulness, transparency, relevance and meaningfulness of the reported information (Note 17). Furthermore, social reporting must have a final and programmatic value, getting the stakeholders involved in a context of active and constructive discussion (Note 18).

As it is known, the preliminary element of the social reporting process in all sectors is mapping, that is the grouping of the stakeholders. Being inserted in the context of public bodies, the stakeholders who communicate with the Chambers Entities are better grouped together on the basis of the following criteria (Note 19) a) public resources destination criterion, $b$ ) public policies destination criterion and $c$ ) localization of public policies criterion. According to the first criterion, the stakeholders can be grouped according to the destination of public transfers. According to the second criterion, instead, the stakeholders are to be grouped based on the function of the destination of the services offered whereas, according to the third criterion, the stakeholders are grouped on the basis of the territory of action of the Entity.

Please note that both the literature and the several guidelines have offered, over time, multiple solutions regarding the structure of the social reports. Such solution often engulf constructs that are realized through the hypothetical-deductive method (Note 20). The experiences of the Chambers of commerce when it comes to social reporting, though, are so heterogeneous as to not allow to come to certain conclusions regarding the dominant standard of use. The vastness of social reports produced, indeed, makes it so that each one of these shows some peculiarities that are significant under a structural and content level (Note 21). However, such vastness is not wrong, if we think of the methodological enhancement that the voluntary character of it linked to social reporting allows to have. For this reason it is possible to propose a social report sample (in our specific case we would use a social accountability report) that is the reflection of what is normally in use among the several Chambers and therefore integrated amongst the Chamber entities (Note 22). In order for the sample integrated social accountability report to represent a perfect synthesis of the samples in use, it is necessary to proceed to a reasoned selection of the elements observed so that they can become important. Such selection is reported in Table 2.

Table 2. Social accountability report diagram integrated for the Chambers of Commerce

\begin{tabular}{lllll}
\hline Preface & Introduction & $\begin{array}{l}\text { Chamber's } \\
\text { identity }\end{array}$ & Social Relp & $\begin{array}{l}\text { Economic } \\
\text { relationship }\end{array}$ \\
\hline $\begin{array}{l}\text { Letter to the } \\
\text { President }\end{array}$ & $\begin{array}{l}\text { Purpose of } \\
\text { social } \\
\text { accountability } \\
\text { report }\end{array}$ & Mission & $\begin{array}{l}\text { Identification of the } \\
\text { stakeholders }\end{array}$ & $\begin{array}{l}\text { Production of } \\
\text { added value }\end{array}$ \\
\hline
\end{tabular}




\begin{tabular}{|c|c|c|c|}
\hline $\begin{array}{l}\text { Methodological } \\
\text { profiles }\end{array}$ & Values & $\begin{array}{l}\text { stakeholders' mapping and } \\
\text { stakeholder-activity matrix }\end{array}$ & $\begin{array}{l}\text { Distribution of } \\
\text { added value }\end{array}$ \\
\hline \multirow[t]{8}{*}{ Working group } & Functions & $\begin{array}{l}\text { customer satisfaction } \\
\text { survey }\end{array}$ & $\begin{array}{l}\text { Multiplying } \\
\text { effect }\end{array}$ \\
\hline & $\begin{array}{l}\text { Strategic } \\
\text { intervention }\end{array}$ & Stakeholder engagement & \\
\hline & $\begin{array}{l}\text { Institutional and } \\
\text { Organizational } \\
\text { set-up }\end{array}$ & $\begin{array}{l}\text { Enterprises and territory } \\
\text { action policies }\end{array}$ & \\
\hline & $\begin{array}{l}\text { Chambers of } \\
\text { Commerce } \\
\text { Network }\end{array}$ & $\begin{array}{l}\text { Organization's } \\
\text { development policies }\end{array}$ & \\
\hline & $\begin{array}{l}\text { Institutional } \\
\text { Relationships }\end{array}$ & Performance Cycle & \\
\hline & $\begin{array}{l}\text { Socio Economic } \\
\text { Context }\end{array}$ & Management dashboard & \\
\hline & $\begin{array}{l}\text { Regulation } \\
\text { Context }\end{array}$ & Balance Scorecard & \\
\hline & & Pareto & \\
\hline
\end{tabular}

Source: adaptation from Oliva (2016, p.109)

The outline, therefore, includes five sections: Preface, Introduction, Chamber's identity, Social Reporting and economic report. The most significant sections, in terms of our objectives are the social reporting and the economic report, that will be examined (Note 23).

Social Reporting

$\checkmark$ Identification of the stakeholders. In this section we identify the social aggregate involved in the operations of the Chamber's Entity. The most relevant stakeholders for the Chambers of Commerce can be: the system of enterprises and professions, the users of the chamber's services, the public administration, the chamber system in its whole, the human resources, the community and the trade associations.

$\checkmark$ Mapping of the stakeholders. Through a mapping of the stakeholders, the work group proceeds to the schematic grouping of the stakeholders and of the specific interests they carry. Later on, a matrix is created (known as stakeholder-activity matrix) that is needed to show the distribution of the chamber's activities divided by stakeholder type. It is, indeed, made up of a as many columns as the number of the stakeholders and as many rows as the number of activities planned by the Entity in relation to the interested parties.

$\checkmark$ customer satisfaction survey In this section, the Chamber reports the results of the statistical survey meant to measure the level of satisfaction of the stakeholders regarding the services offered, the activities carried out and the results obtained.

$\checkmark$ Stakeholder engagement. Through the stakeholders engagement, the document measures the needs and the expectations of the stakeholders in order to improve the process of creation of shared social value.

$\checkmark$ Enterprises and territory action policies. This section explains the action policies meant to support enterprises involving, for example, the context of the administrative services, of the protection of the market, of the modernization and internationalization of the processes - and territories, like for example, the area of territorial marketing and of development of the infrastructure network.

$\checkmark$ Organization's development policies. This section explains the Chambers' organization in terms of communication, strategic management, quality and organizational innovation.

$\checkmark$ Performance cycle. This section is dedicated to the monitoring of the results obtained compared to the objectives set, taking into account the planning of actions deemed useful to obtain them and the restrictions met during their completion. 
$\checkmark$ Management dashboard. The management dashboard constitutes an advanced management control system based on the use of an online platform able to provide timely data and information on the ordinary management and the strategies employed.

$\checkmark$ Balanced scorecard. This is a particular management system of the social performances based on the employment of four specific indicators - involving the economic-financial area, the local economic system, the internal processes, the growth and learning innovation - and three levels of evaluation: low performance (red signal), average performance (yellow signal) and excellent performance (green signal).

$\checkmark$ Pareto. Pareto is an online platform that allows comparison of specific chamber performances with best practices, using several mathematical-statistic indicators. These indicators are grouped according to the so called panels, and concern programming, efficiency, services and performances of the Special Companies.

Economic reporting

$\checkmark$ Production of added value. This section is dedicated to quantifying the added value produced by the Chamber of commerce and redefined in the light of an appropriate reclassification of the income statement.

$\checkmark$ Distribution of added value. After calculating the added value, its distribution among the stakeholders (such as the economic-productive system, the Chamber itself, the other entities of the Chambers system, the Public administration and the credit system) is examined.

$\checkmark$ Multiplying effect. The multiplying effect measures the spreading of the social effects of the actions of the Chamber in terms of amplification of the range and the socio-economic effects of the Chamber's action.

\section{A Few Empirical Evidences}

Table 3 shows the inland distribution of social reports amongst the Chambers of commerce between 1999 and 2016. As it can be observed, considering 105 Chambers of commerce (Note 24), 63 of them have edited a social report, that is $60 \%$ of them in terms of percentage. Moreover, among the Chambers of Commerce considered, 41 have provided a social report (for a percentage of 39,04\%) versus 33 Chamber Entities that have edited a social accountability report (a percentage of $31,42 \%$ ). Finally, the number of Chambers of commerce that have provided both reports, amounts to 10 units, for a percentage al 9,52\%; 5 of these (Bergamo, Milano, Varese, Verbano-Cusio-Ossola e Treviso) are located in the north, 1 (Perugia) in the center 4 (Potenza, Vibo Valentia, Campobasso e Agrigento) in the South. Furthermore, in the whole, the chambers Entities have preferred to edit a social report rather than a social accountability report. As a matter of fact, of the 91 social reports produced by the Chambers over time, 56 are social reports and 35 are social accountability reports. Therefore, in terms of percentage, $61,53 \%$ of the reports produced by the Chambers are social reports whereas 38,47\% are social accountability reports. Moreover, among the several Chambers of commerce, 12 have particularly stood out for having produced several reports over time. Viterbo, in particular, has produced, between 2007 and 2014, 4 social reports, followed by Verbano-Cusio-Ossola with 3 social reports, between 2006 and 2010, and Prato with 3 social reports between 2007 and 2010. The remaining 9 Chambers of commerce, instead, have produced 2 social reports on average and are mostly focused in the North. Furthermore, on a regional level, the number of Chambers of Commerce that have produced one or two reports amounts to 29 units in the North (46,03\%), 13 in the Centre $(20,63 \%)$ and 21 in the South $(33,34 \%)$. Also, the number of Chambers of commerce that have only produced the social report are distributed as follows: 15 are in the North (36,58\%), 9 in the Centre $(21,95 \%)$ and 17 in the South $(41,47 \%)$. Finally, the number of Chambers of commerce that have only produced the social accountability report are distributed as follows: 19 in the North $(57,57 \%), 5$ in the Centre $(15,15 \%)$ and 9 in the South $(27,28 \%)$.

Table 3. Social reporting in the Chambers of Commerce (1999-2016).

\begin{tabular}{|c|c|c|c|}
\hline Regions & CCIAA & Social Report & $\begin{array}{c}\text { Social Accountability } \\
\text { Report } \\
\end{array}$ \\
\hline \multicolumn{4}{|l|}{ North } \\
\hline \multicolumn{4}{|c|}{ Emilia-Romagna } \\
\hline & Bologna & - & - \\
\hline & Ferrara & - & - \\
\hline & Forlì-Cesena & - & - \\
\hline & Modena & - & n.d. \\
\hline & Parma & - & $1999-2008$ \\
\hline
\end{tabular}


Friuli-Venezia

Giulia

Gorizia

Pordenone

Trieste

Udine

Liguria

Genova

Imperia

La Spezia

Savona

Lombardia

Bergamo

Brescia

Como

Cremona

Lecco

Lodi

Mantova

Milano

Monza e Brianza

Pavia

Sondrio

Varese

Piemonte

Alessandria

Asti

Biella

Cuneo

Novara

Torino

Verbano-Cusio-Ossola

Vercelli

Trentino-Alto

Adige

Bolzano

Trento

Valle d'Aosta

Aosta

Veneto

Belluno

Padova

Rovigo

Treviso

Venezia
- $\quad 2008$

- $\quad-$
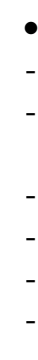

-

-

-

-

$-$

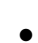

-

$-$

$-$

$$
\text { - }
$$

-$$
\bullet
$$

-

$-$

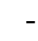

$-$

$-$

$-$

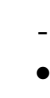$$
\bullet
$$$$
\text { - }
$$

n.d.

2014

2015

-

2003

-

$-$

$-$

n.d.

2014

2015

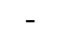

$-$

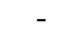

$-$

2006

2008

2010

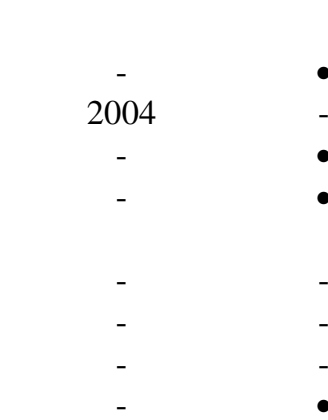

- 2011-2015

- 2010-2014

2000-2002

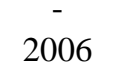

- 2007-2012

-

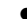

-

2009-2014

2008-2012

2004-2009
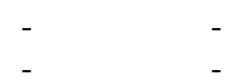

-

- 2006

- 2002-2003

- 2004-2005

- 2010

- $\quad 2012$
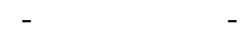
Verona

Vicenza

$\underline{\text { Center }}$

Lazio

Frosinone

Latina

Rieti

Roma

Viterbo

Marche

Ancona

Ascoli Piceno

Fermo

Macerata

Pesaro-Urbino

Toscana

Arezzo

Firenze

Grosseto

Livorno

Lucca

Massa Carrara

Pisa

Pistoia

Prato

Siena

Umbria

Perugia

Terni

South

Abruzzo

Basilicata

Chieti

L'Aquila

Pescara

Teramo

Matera

Potenza

Calabria

Catanzaro

Cosenza

Crotone

Reggio Calabria

Vibo Valentia
- 2004-2005

$\begin{array}{lc}- & - \\ \text { - } & 2009 \\ \text { - } & 2011 \\ \text { - } & 2001-2003 \\ \text { - } & - \\ \text { - } & 2007 \\ \text { - } & 2008 \\ \text { - } & 2012 \\ \text { - } & 2014 \\ \text { - } & 2008 \\ \text { - } & - \\ \text { - } & - \\ \text { - } & 2004-2006\end{array}$

- 2003-2005

- 2007-2011

$-2$
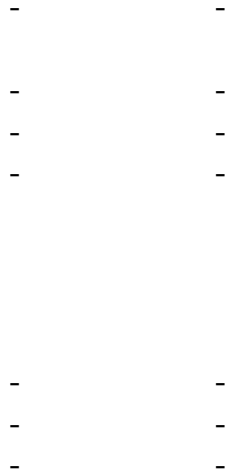

2002-2007

2009-2014

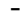

$-$

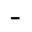

$-$

2007

2009

2010

2008

2014

- 2006-2007

2009-2014

- $\quad$ 2009-2011

- $\quad$ -

- 2006

- 2007

- 2003

-

- 2005-2006

- 2005-2006

2009-2014

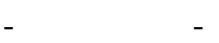

- 2015

- 2006-2008

- $\quad$ -

- 2004-2005

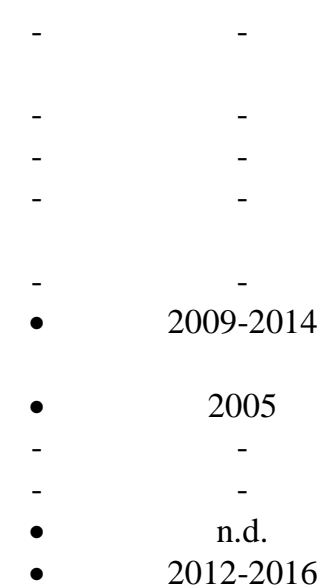




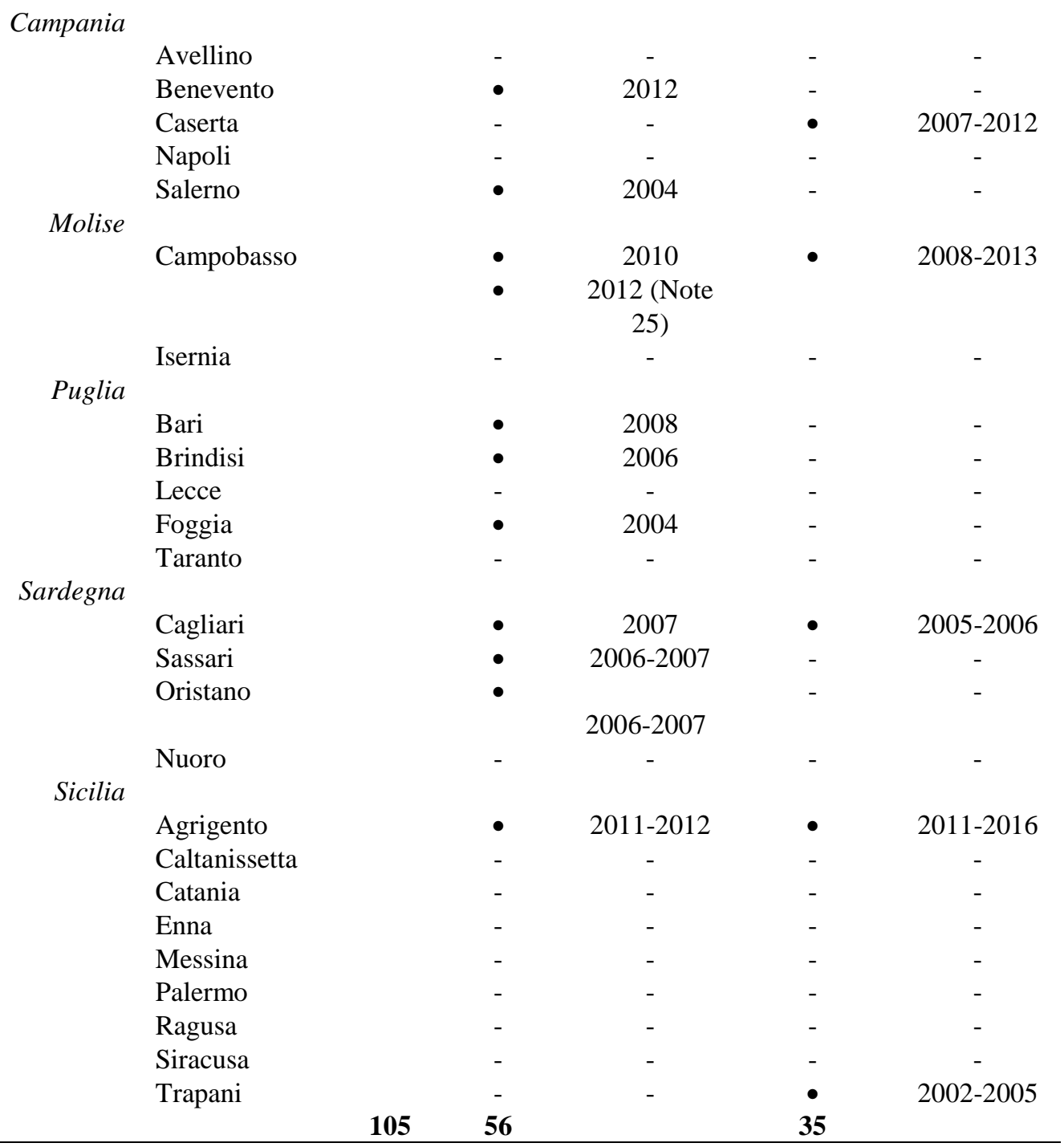

Source: personal processing and Unioncamere's data (Note 26).

The territorial distribution of social reporting in the Chambers of Commerce can be better observed through Figure 2: 


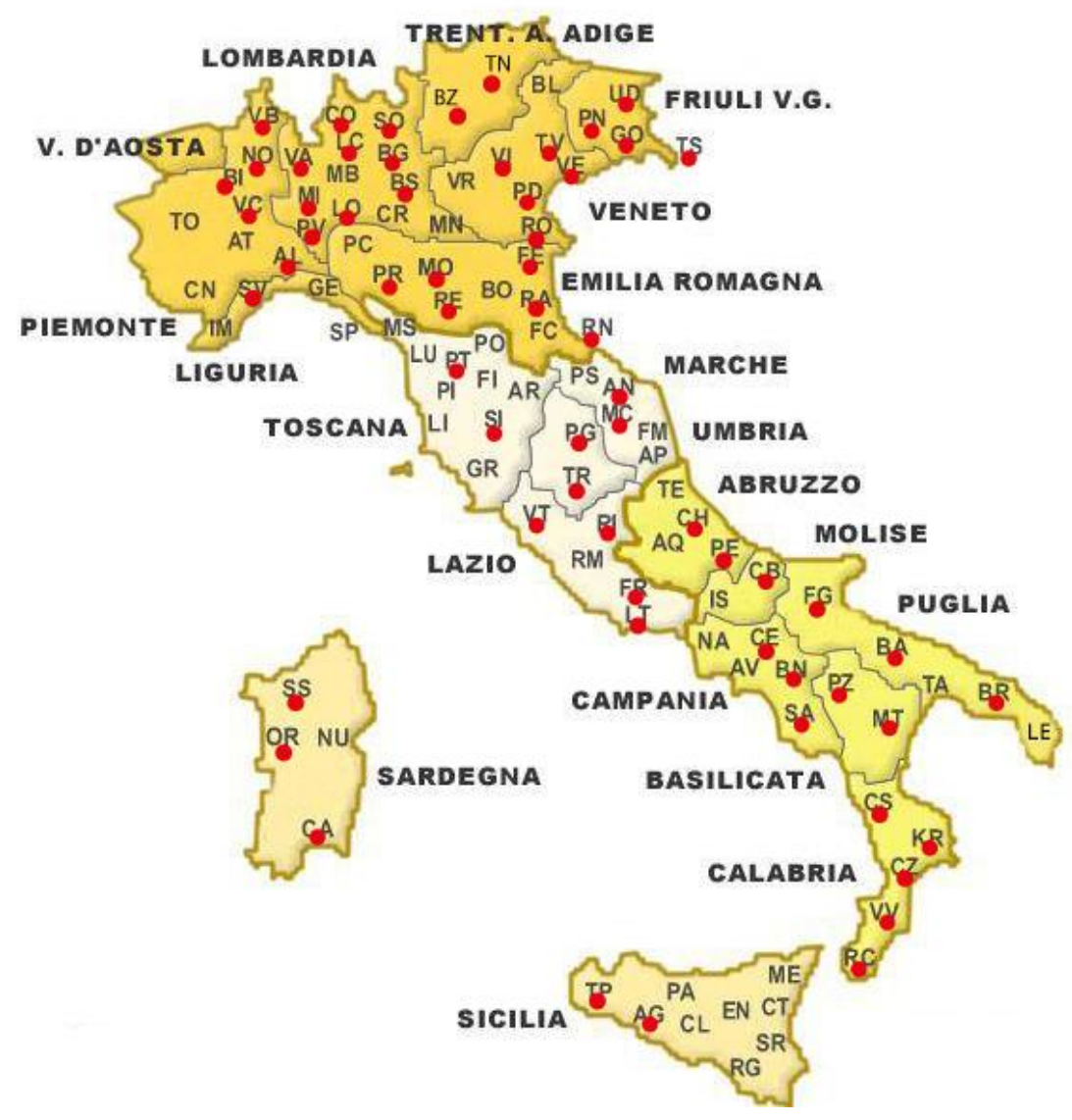

Figure 2. Mapping of social reporting in the Chambers of Commerce

Source: our on processing on data in Table 3.

\section{The Social Accountability Report of Treviso (2011-2015): Elements of Convergence with and Divergence from the Integrated Balance}

The Chamber of Commerce of Treviso is one of the few Italian chamber realities that are more active in the area of social reporting in the specific case of the (social) accountability report. Non only it has produced - together with the Chamber of Commerce of Agrigento, Vibo Valentia and Savona - a (social) accountability report in the last five years, but, together with the Chamber of Commerce of Frosinone, it has a more dynamic history of reporting, having produced two consecutive social accountability reports (one in the period from 2006 to 2010 and another in the period from 2011 to 2015).

Please note that the report that is analyzed here is formally a social accountability report but we intend it to also be a social report since it includes a series of information that are typical of the social report. Such typical characteristic, though, as we will better observe later on, does not make it perfectly compatible with the report outline indicated in Figure 2.

Aside from statistic peculiarities that interest the Chamber of Commerce of Treviso, the choice to examine its social accountability report is justified by the will to reflect on the social reporting modalities and on the effects produced by an Entity located in another strongly entrepreneurial area (Note 27) that despite the losses experienced because of the crisis in the last few years, it still is considered the "Locomotive of the North East, and that, in a global scenario is still in the spotlight for its real economic system, made out of fine manufacturing, high added value services, renown agro-food products" (Note 28).

The social accountability report of the chamber of commerce of Treviso is made out of three macro-sections (aside from the preface of the President): the first one reports information regarding the Chamber's identity, the second 
pertains the production of added value, the third shows information regarding the territory and entrepreneurial structure promotional activity, the fourth part describes the service activities of the chamber Entity. Finally, the document ends with a social report. The context of reference, the history of the Chamber, its mission, the governance and organization and finally the Chamber's network are an integral part of the first section of the document.

What emerges from the section dedicated to the context of reference, aside from the usual demographic data and the economic aggregated, is mostly the positioning in terms of quality of life $\left(566 / 600\right.$ points and $23^{\circ}$ place on a national scale), low unemployment rate (8,3\%), high tendency to internationalization and export, and the positive balance of the commercial scale (Note 29). In the section dedicated to its history, a very interesting information is the complex of activities - certified, in particular, on the basis of Regulation UNI EN ISO 9001:2008 and EFQM - aimed at the improvement of the quality of the services offered and to the efficiency and cost effectiveness of the administrative and promotional activities (Note 30). In terms of mission, the Chamber of commerce of Treviso "identifies as a point for aggregation of entrepreneurial interests that are different yet united by the common project to realize a system of incentives and benefits that will be useful to the entire territorial economic community" (Note 31). Certification and administration, as well as study and territorial development planning, together with market regulation and economic promotion are going to be the institutional functions that will support the mission (Note 32). Also, the Board, the Council the President, the Board of Auditors and the Evaluation Body (Note 33) are an integral part of the governance. Finally, the Chamber's network is made out of 14 companies of which 2 are subsidiary companies, 6 are companies in the territory that are Chamber's affiliate companies and 6 are companies of the Chamber system controlled by the Entity (Note 34).

The second section, as disclosed earlier, inspects the production of added value. The chamber Entity has even added a part dedicated to the multiplying effect to it. In the five years between 2011 and 2015 the Entity has registered a gross income adding up to euro 82.876.620,19. It derives from the difference between a total of current earnings amounting to $112.098 .065,89$ and a total of operation costs amounting to euro 29.221.445,70. Also, in the same period, the gross overall added value has set to euro 85.888.748,39.

Table 4 shows the determinants and the values (absolute and relative) of the items regarding the gross overall added value.

Table 4. The gross global added value of the Chamber of Commerce of Treviso (2011-2015)

\begin{tabular}{lcc}
\hline \multicolumn{1}{c}{ Indicators } & Absolute values & Relative values \\
Total Gross Income & $82.876 .620,19$ & $96,49 \%$ \\
Financial Income & $2.131 .723,38$ & $2,48 \%$ \\
Financial expenses & 0,00 & $0,00 \%$ \\
Financial management balance & $2.131 .723,38$ & $2,48 \%$ \\
Revaluation of Assets & 0,00 & $0,00 \%$ \\
Depreciation of Assets & $-140.571,70$ & $-0,16 \%$ \\
Value adjustment to financial assets balance & $-140.571,70$ & $-0,16 \%$ \\
Extraordinary Income & $3.289 .355,89$ & $3,83 \%$ \\
Extraordinary expenses & $-2.268 .379,37$ & $-2,64 \%$ \\
Non recurring income balance & $1.020 .976,52$ & $1,19 \%$ \\
Gross overall added value & $85.888 .748,39$ & $100,00 \%$ \\
\hline
\end{tabular}

Source: Chamber of Commerce of Treviso, op.cit., pp. 12-14.

In reference to the multiplier, instead, the Chamber of Commerce of Treviso has recorded, in the analyzed period, an amount of resources that have generated the same effect, amounting to euro 7.050.000 and evaluating the effect in euro 56.400.000. Considering the gross overall added value, adding up to $85.888 .748,39$, it is easy to note the ability of the Entity to generated over 140 million of euro in favor of the stakeholders and the territory in general (Note 35).

Regarding the promotional activity of the territory and the entrepreneurial fabric, the document shows the activity of the Chamber to promote, first of all, the internationalization of the enterprises through the management of the "export documentation, courses, seminaries and specialist training actions [...], support in participation to trade shows [and] organization of events and incoming/outgoing missions" (Note 36). In the period considered, in detail, 
the economic resources destined to the internationalization have amounted to euro 3.903.534. There have been 78 training actions (courses, seminaries and conferences) for those interested in the processes of internationalization, involving 2971 participants and 958 enterprises. The most interesting geographical areas in the process of internationalization of local enterprises have been Europe, followed by Asia and South America. The Chamber has furtherly distinguished itself for having created several initiatives to sustain new entrepreneurial realities, female entrepreneurial realities and the enterprises network. One interesting initiative put in place by the Chamber involves the integrated rating which represents a research project aimed at evaluating the credit rating in the long term, considering the assets and the risks as well as the companies' performances. The Chamber has also activated a CSR counter meant to provide services and financing to sustain the enterprises' social accountability and environmental sustainability, assigning, in the five year period considered, resources for euro 281.516. Also, in the same period, there have been 13 traditional courses and 78 e-learning training courses regarding social and environmental responsibility involving (in the whole) 232 participants. There have also been 5 dedicated convention involving 274 participants (Note 37). The document, then, continues, as mentioned above, with a section dedicated to service activities, providing interesting data on the administrative services, on the market regulation and on the information services for enterprises and territory (Note 38).

Finally, the document ends with the real social report. The stakeholders that are the recipients of the social report of the Chamber of Commerce of Treviso are its employees and users. According to its statements, "[the entity] follows a path of constant improvement both toward its employees (performance plans, organizational wellbeing surveys, etc.) and toward the public (services chart, customer satisfaction surveys, etc.)" (Note 39). Regarding personnel, the Chamber has a good $97,58 \%$ of full time employees. Regarding gender, 7,4\% of personnel is made out of women and $33 \%$ are the female managers. About $80 \%$ of personnel declares to be satisfied with working for the Entity. Most of the satisfaction derives, in particular, from the high level of autonomy in managing the work activity and from the level of internal involvement. Regarding the relationships with the users, the Entity shows how half of its users interviewed for the customer satisfaction procedure declares itself satisfied by the Chamber and the chamber's services as a whole. Most of the satisfaction is expressed toward the services related to market regulation as well as studies and financial analysis, while the lowest level of satisfaction is observed toward communication activities.

From the analysis of the report of the Chamber of Commerce of Treviso emerges, as it can be observed, a good convergence toward the integrated social accountability report structure developed in par.4. The presence of a series of content gaps, though, does not make it perfectly compatible with the outline proposed. They mostly concern the parts related to the methodology, the mapping of the stakeholders, the stakeholder-activity matrix, the performance cycle, and the added value distribution. As long as proposals are concerned, the outline of the integrated social accountability report for the Chambers of Commerce presented here, proves to be a standard of reference, since it provides a series of indicators generally used that can sensibly improve the quality of reporting in the single Chamber of Commerce.

\section{Conclusions}

The subject of social responsibility and its reporting has acquired, over time, an increasing importance both in the private and in the public sectors. Also, in the public sector, the Chambers of commerce are more orientated toward employing different social reporting solutions, so as to guarantee greater transparency and management data accessibility as well as the employment of its resources within the principles of accountability and social control. After analyzing the features and the theoretical and methodological criticalities of social reporting in general, the work focuses on the social accountability report of the Chambers of commerce as a non-accounting tool aimed at spreading a systemic and structured vision of the activities carried out and the results obtained by the administration, with reference to the time span of the ending mandate. The work, then, develops further, proposing a social reporting standard and showing, through the analysis of a case study (the social report of the Chamber of Commerce of Treviso), the complexity of the phenomenon and the issues regarding the convergence toward that same standard. Finally, the work is integrated by an empirical analysis meant to show the territorial composition and distribution of the two main forms of reporting (the social report and the social accountability report. From such analysis there emerges a higher diffusion of the social report compared to the social accountability report and a higher concentration of reports in the northern area. Nonetheless, the southern Chambers of commerce appear to be particularly active in the process of social reporting, unlike the central area's Chambers, to the point of being a positive example for the chambers' realities in the North.

\section{References}

Borghi, A. (1997). Il bilancio del mandato amministrativo. Azienditalia, 7, 388-395. 
Campedelli, B. (2005). Reporting aziendale e sostenibilità. FrancoAngeli, Milano.

Catturi, G. (2004). Oltre la dicotomia pubblico-privato: la persona al centro dell'erogazione dei servizi. Rivista Italiana di Ragioneria e di Economia Aziendale, 11-12, 644-660.

Cisi, M. (2003). Il bilancio ambientale. Giappichelli, Torino.

Comite, U. (2009). Social balance as a model of reporting accounts of the Italian chamber of commerce, Oxford Business \& Economics Conference, Oxford.

Elkington, J. (1998). Cannibal with Forks. The triple bottom line of 21 st century business, Capstone Publishing LTD, Oxford.

Farneti, G., \& Pozzoli, S. (2005). Bilancio sociale di mandato. Ipsoa, Milano.

Fiorentini, G., \& Preite, D. (2000). Azienda pubblica e azienda non profit: il ruolo del bilancio sociale nel decentramento. Azienda Pubblica ${ }^{\circ}$ 2, 3, Maggioli, Rimini.

Gabrovec, Mei O. (2004). Valore aggiunto e bilancio: l'esperienza dello standard GBS. In G. Rusconi e M. Dorigatti (a cura di), Teoria generale del bilancio sociale e applicazioni pratiche, Milano, FrancoAngeli.

Gervasoni, S. (2000). Sistemi di gestione ambientale. Hoepli, Milano.

Giusepponi, K. (2004). Il bilancio sociale negli Enti locali, Contenuti e relazioni con il controllo di gestione. Giuffrè, Milano.

Grossi, G. (2004). Il bilancio consolidato negli Enti locali. Cedam, Padova.

Guarini, E. (2002). Prospettive di bilancio sociale negli Enti locali. Azienda pubblica, 6, 711-735.

Lepore, G., \& Capraio, M. (2003). I sistemi di gestione ambientale. FrancoAngeli, Milano.

Manni, F. (2006). Considerazioni sul bilancio sociale in ambito pubblico. Aracne, Roma.

Marcuccio, M. (2002). Rendicontazione sociale e aziende pubbliche locali: uno strumento di accountability e controllo strategico. Azienda Pubblica, novembre - dicembre, 2002, Maggioli, Rimini.

Martinelli, A. (2002). Il modello Comunità e impresa: stakeholder e responsabilità sociale. In L. Hinna (a cura di), Il bilancio sociale, Il Sole 24 Ore, Milano.

Mazzara, L. (2004). Bilancio di mandato e bilancio sociale: unico documento?. Azienditalia, 1, 13-21.

Mussari, R. (1996). L'azienda del comune tra autonomia e responsabilità. Cedam, Padova.

Oliva, N. (2016). Il bilancio sociale integrato per le Camere di Commercio. Una proposta alla luce dell'esperienza lombarda. FrancoAngeli, Milano.

Pavan, A., \& Reginato, E. (2012). Programmazione e controllo nelle amministrazioni pubbliche. Gestione per obiettivi e contabilità integrata. Giuffrè, Milano.

Preite, D. (2005). Bilancio consolidato e informazione per il gruppo pubblico locale. Egea, Milano.

Rogate, C., \& Tarquini, T. (2004), Il bilancio sociale negli Enti locali. Maggioli, Rimini.

Romanazzi, S., \& Intranuovo, A. (2015). La rendicontazione sociale nella Camera di commercio. In A. F. Uricchio A. F., Mongelli G., Partipilo A. P., \& Petrucci S. (a cura di), Le Camere di commercio. Profili istituzionali e gestionali degli Enti al servizio delle impese (pp. 741-774.). Roma, Aracne editrice.

Romolini, A. (2007). Accountability e bilancio sociale negli Enti locali. FrancoAngeli, Milano.

Siboni, B. (2007). La rendicontazione sociale negli Enti locali. FrancoAngeli, Milano.

Tanese, A. (a cura di) (2004). Rendere conto ai cittadini. Il bilancio sociale nelle amministrazioni pubbliche. Rubettino, Napoli.

Unioncamere. (2005). Il sistema camerale. Il bilancio sociale delle Camere di commercio. I Focus di Unioncamere 2005 sul bilancio sociale.

Unioncamere. 1999-2009 Dieci anni di rendicontazione sociale nel Sistema Camerale. Caratteristiche, uniformità, evoluzioni. 2011 Retecamere, Roma.

Valeri, M. (2004). I progetti innovativi per la tutela ambientale nelle strategie di imprese. FrancoAngeli, Milano. 


\section{Notes}

Although this work is the result of shared project, paragraphs 1,2,3 are ascribable to Ubaldo Comite, whereas paragraphs 4,5 and 6 to Nadia Oliva. The conclusions are attributable to both.

Note 1. Reg n ${ }^{\circ} 58029$ December 1993, Reorganization of the chambers of commerce, industry, handicraft and agriculture, in G.U. 11 January 1994, n. 7, S.O.

Note 2. Lgs. D n'23, 15 February 2010 Reform of the set of rules related to the Chambers of Commerce, Industry, handicraft and agriculture, in the fulfillment of art. 53, Law no.99 dated 23 July 2009, in G.U. 25 February 2010 no.46.

Note 3. Dlgs 25 November $2016 n^{\circ} 219$, Implementation of proxies as per art. 10 Law dated 7 August $2015 n^{\circ} 124$, for the reorganization of the function and the financing of the Chambers of Commerce, Industry, Handicraft and Agriculture in G.U. 25 November 2016 n 276.

Note 4. Elkington J., Cannibal with Forks. The triple bottom line of 21 st century business, Capstone Publishing LTD, Oxford, 1998.

Note 5. Comite U., Social balance as a model of reporting accounts of the Italian chamber of commerce, Oxford Business \& Economics Conference, Oxford, 2009.

Note 6. Martinelli A., Il modello Comunità e impresa: stakeholder e responsabilità sociale, in L. Hinna (a cura di), Il bilancio sociale, Il Sole 24 Ore, Milano, 2002.

Note 7. Fiorentini G., Preite D., Azienda pubblica e azienda non profit: il ruolo del bilancio sociale nel decentramento, Azienda Pubblica n², 3, 2000, Maggioli, Rimini.

Note 8. Marcuccio M., Rendicontazione sociale e aziende pubbliche locali: uno strumento di accountability $e$ controllo strategico, Azienda Pubblica, November - December, 2002, Maggioli, Rimini.

Note 9. Manni F., Considerazioni sul bilancio sociale in ambito pubblico, Aracne, Roma, 2006.

Note 10. Gabrovec Mei O., Valore aggiunto e bilancio: l'esperienza dello standard GBS, in G. Rusconi, M. Dorigatti (supervised by), Teoria generale del bilancio sociale e applicazioni pratiche, F. Angeli, Milano, 2004.

Note 11. Oliva N., Il bilancio sociale integrato per le Camere di Commercio. Una proposta alla luce dell'esperienza lombarda, FrancoAngeli, Milano, 2016, p.62. See also Romolini A., Accountability e bilancio sociale negli Enti locali, FrancoAngeli, Milano, 2007, pp. 91-92.

Note 12. Romolini A., op. cit., p. 36.

Note 13. Pavan A. e Reginato E., Programmazione e controllo nelle amministrazioni pubbliche. Gestione per obiettivi e contabilità integrata, Giuffrè, Milano, 2012, p.18.

Note 14. Borghi A., Il bilancio del mandato amministrativo, Azienditalia, 1997, 7, pp. 388-395; Guarini E., Prospettive di bilancio sociale negli Enti locali, Azienda pubblica, 2002, 6, pp. 711-735; Giusepponi K., Il bilancio sociale negli Enti locali, Contenuti e relazioni con il controllo di gestione, Giuffrè, Milano, 2004; Mazzara L., Bilancio di mandato e bilancio sociale: unico documento?, Azienditalia, 2004, 1, pp. 13-21; Tanese A. (a cura di), Rendere conto ai cittadini. Il bilancio sociale nelle amministrazioni pubbliche, Rubettino, Napoli, 2004; Farneti G. e Pozzoli S., Bilancio sociale di mandato, Ipsoa, Milano, 2005; Romolini A., op. cit.

Note 15. S. for example Gervasoni S., Sistemi di gestione ambientale, Hoepli, Milano, 2000; Cisi M., Il bilancio ambientale, Giappichelli, Torino, 2003; Lepore G. e Capraio M., I sistemi di gestione ambientale, FrancoAngeli, Milano, 2003; Valeri M., I progetti innovativi per la tutela ambientale nelle strategie di imprese, FrancoAngeli, Milano, 2004.

Note 16. Romolini A., op. cit., cap. 3; Catturi G., Oltre la dicotomia pubblico-privato: la persona al centro dell'erogazione dei servizi, Rivista Italiana di Ragioneria e di Economia Aziendale, 2004, 11-12, pp. 644-660; Grossi G., Il bilancio consolidato negli Enti locali, Cedam, Padova, 2004; Preite D., Bilancio consolidato e informazione per il gruppo pubblico locale, Egea, Milano, 2005.

Note 17. Romolini A., op. cit., cap. 4.

Note 18. S. also Campedelli B., Reporting aziendale e sostenibilità, FrancoAngeli, Milano, 2005.

Note 19. Romolini A., op. cit., p. 45. 
Note 20. See for example Romanazzi S. e Intranuovo A., La rendicontazione sociale nella Camera di commercio, in A. F. Uricchio A. F., Mongelli G., Partipilo A. P. and Petrucci S. (supervised by), Le Camere di commercio. Profili istituzionali e gestionali degli Enti al servizio delle impese, Roma, Aracne publishing, 2015, pp. $760-770$ and the guidelines proposed by Unioncamere.

Note 21. From such heterogeneity it is possible, moreover, to grasp the importance of accountability in public administration, especially in terms of the subjects involved, of the object of the reporting, of the reporting tools and techniques and, eventually, of the communication channels used, (s. Mussari, 1996).

Note 22. Oliva N., op. cit., pp. 109-106. Please note that the integrated reporting method proposed initially by Oliva strictly concerns the social report, but at the same time it might be extended to other types of social reporting, such as the social accountability report. For this reason, and adaptation of it is proposed here.

Note 23. For a detailed study of the remaining section please see Oliva N., op. cit., pp. 109-106.

Note 24. Please note that Table 1 does not take into account the merging of the Chambers of Commerce following the recent Legislative Decree dated 25 November 2016, no. 219, carrying "fulfilment of mandate as per art. 10 of regulation dated 7 August 2015, n. 124, for the reorganization of the functions and the financing of the chambers of commerce, industry, handicraft and agriculture" Since both the social reports and the social accountability reports have been edited before the reform.

Note 25. Gender Social Report.

Note 26. Unioncamere, 1999-2009 Dieci anni di rendicontazione sociale nel Sistema Camerale. Caratteristiche, uniformità, evoluzioni, 2011 Retecamere, Roma - report not edited, • report edited, n.d. missing data not provided by Unioncamere and not available on line.

Note 27. With 90\% active enterprises up until 2015 (v. Chamber of Commerce of Treviso, end-of-mandate report 2011-2015, 2016, p. 4.

Note 28. Chamber of Commerce of Treviso, op. cit. p. 2

Note 29. Chamber of Commerce of Treviso, op.cit., p. 4.

Note 30. Chamber of Commerce of Treviso, op.cit., p. 6.

Note 31. Chamber of Commerce of Treviso, op.cit., p. 6.

Note 32. Chamber of Commerce of Treviso, op.cit., p. 6.

Note 33. Chamber of Commerce of Treviso, op.cit., p. 6.

Note 34. Data on 31/12/2015. V. Chamber of Commerce of Treviso, op.cit., pp. 7-9.

Note 35. Chamber of Commerce of Treviso, op.cit., p. 14.

Note 36. Chamber of Commerce of Treviso, op.cit., p. 16.

Note 37. For an in-depth analysis of the sections dedicated to entrepreneural activities and enterprises network, studies and economic training, environment and social responsability, and to the protection of industrial property please see Chamber of Commerce of Treviso, op.cit., pp. 19-29.

Note 38. Please see Chamber of Commerce of Treviso, op.cit., pp. 31-37.

Note 39. Chamber of Commerce of Treviso, op.cit., p.39. 